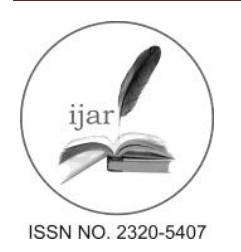

Journal homepage: http://www.journalijar.com
Journal DOI: 10.21474/IJAR01

INTERNATIONAL JOURNAL

OF ADVANCED RESEARCH

RESEARCH ARTICLE

\title{
THE PECULIARITIES OF FORMATION OF THE STRUCTURE OF THE CABINET OF MINISTERS
} OF THE REPUBLIC OF UZBEKISTAN.

Botu Babirovich Alimov.

The lecturer of the department "State law and governance" at the Tashkent State University of Law.

\author{
Manuscript Info \\ Manuscript History: \\ Received: 10 May 2016 \\ Final Accepted: 19 June 2016 \\ Published Online: July 2016 \\ Key words: \\ The Constitution, Cabinet of \\ Ministers, Government, Prime \\ Minister, the Oliy Majlis, \\ Parliament, President, head of the \\ government, to approve, to appoint, \\ members of the Cabinet of \\ Ministers, political party. \\ *Corresponding Author
}

Botu Babirovich Alimov.

\begin{abstract}
In this article, the formation of the Cabinet of Ministers of the Republic of Uzbekistan, that is, the process of approval of the Prime Minister and appointment of members of the government, and peculiarities of participation of the President and the country's Parliament in this process are thoroughly analyzed, proposals aimed at improving the legislation in this sphere are developed by the author.
\end{abstract}

The process of formation of the Cabinet of Ministers in the Republic of Uzbekistan is one of the most important constitutional and legal institutions, and direct participation of the head of the government and the supreme representative body will be provided in its implementation. The formation of the Cabinet of Ministers of the Republic of Uzbekistan is a complicated and important process, and the progress of this process and its results directly affects the stability of governmental mechanism and effectiveness of government administration.

The order of formation of the Cabinet of Ministers, which is the main body of the executive power in the Republic of Uzbekistan have been gradually improved in conditions of implementation of democratic reforms in our country. In particular, these legal relations acquire new meaning in amendments and additions introduced to the Constitution of the Republic of Uzbekistan in 2003, 2007, 2011, 2014, as well as a number of legislative acts adopted on their basis. Today, relations on formation of the Cabinet of Ministers of the Republic of Uzbekistan are legally regulated in detail in the Constitution of the Republic of Uzbekistan, Constitutional laws "On the Legislative Chamber of the Oliy Majlis of the Republic of Uzbekistan", "On the Senate of the Oliy Majlis of the Republic of Uzbekistan", "On strengthening the role of political parties in renewal of the state control and further democratization and modernization of the country", and the Laws "On the Cabinet of Ministers of the Republic of Uzbekistan", "On the Regulations of the Legislative Chamber of the Oliy Majlis of the Republic of Uzbekistan", "On the Regulation of the Senate of the Oliy Majlis of the Republic of Uzbekistan”.

The process of approval of the Prime Minister of the Republic of Uzbekistan has a special place in constitutional and legal relations of formation of the composition of the Cabinet of Ministers of the Republic of Uzbekistan. Like in most countries of the world, the appointment of the head of the supreme executive power in Uzbekistan is the first and the main stage of the process of formation of the governmental structure.

According to the $98^{\text {th }}$ Article of the Constitution of the Republic of Uzbekistan, "The nominee of a Prime Minister of the Republic of Uzbekistan shall be proposed by a political party, securing the highest number of seats in the elections to the Legislative Chamber of the Oliy Majlis of the Republic of Uzbekistan or by several political parties, 
securing the equal highest number of seats" [1, P. 51]. For the first time, the norm of nominating the candidate for the post of Prime Minister of the Republic of Uzbekistan by the political parties was enshrined in the legislation of our country in 2011 [3], and is one of the opportunities in increasing the role of political parties in the life of government and society in the Republic of Uzbekistan as in democratic countries, strengthening their efforts to power with legal way and for further strengthening the multiparty system in our country. The supreme representative body in the process of formation of the structure of the Cabinet of Ministers and participation of political parties is important, and means that the structure of the government cannot be formed without participation of political parties in parliament. Proposal of political parties on the candidate of the Prime Minister is a starting point in the process of formation of the Cabinet of Ministers and an essential requirement. This form of appointment of the Prime Minister to a position serves to increase activity of political parties in the life of the government and society, further expand cooperation of the head of the country with chambers of parliament in a number of important issues such as appointment of the Prime Minister.

Scientist A.A.Azizkhodjaev justifies positive features of this provision as follows: "Firstly, this novelty shows a more democratic nature of formation of the executive power. Secondly, the new order will further increase the responsibility of the Prime Minister before the Parliament. Thirdly, this initiative will serve to strengthen the role of political parties in formation of the executive power. Fourthly, candidacy for the Prime Minister will depend on the results of the elections to the lower house of parliament. This, of course, is a powerful incentive for political parties in our country, is the basis for strengthening the competition between them" [4, P. 493].

If we pay attention to the practice of foreign countries, activeness and decisiveness of participation of parliament in formation of structure of the government in the countries such as Albania, Bulgaria, Macedonia, Moldova, Croatia, Greece, Ireland, Portugal, Turkey, Ukraine, Finland is enshrined in the Constitutions. In some of them, the head of the state consults with political parties on the candidate for the post of the head of the government, in some of them directly by the political parties to this candidate. This is common to all countries and at the same time, there are specific features for each of them, these peculiarities are enshrined in stages of formation of the government, in terms, in the scope of participants, in relations between the subjects of the process, as well as in a number of other factors.

Candidate for the Prime Minister in the Republic of Uzbekistan has not to be be a member or leader of a political party that won the elections (or one of a number of political parties who won few deputy seats in an equivalent or more amount) like in foreign countries (in foreign practice, usually a leader of a political party who won the elections holds the position of the head of a government). Therefore, there is no a legal ban in promotion of a member who is not a member of any political party or member of any other political party to this position (this is almost absent in practice). Our national legislation has been established in such a positive atmosphere that a political party while nominating the candidature of the Prime Minister offer a worthy person not coming out of its interests, but out of the interests of the entire state.

A competent body with its charter of a political party offers candidate for the Prime Minister. Such an offer is introduced to the head of the government not later than two weeks from the date of publication of the list of elected deputies and the information on the results of the elections to the Legislative Chamber of the Oliy Majlis of the Central Election Commission of the Republic of Uzbekistan [2]. The President of the Republic of Uzbekistan, after considering the proposed nominee for the post of Prime Minister, within ten-day term shall propose it for consideration and approval by the chambers of the Oliy Majlis of the Republic of Uzbekistan [1, P. 51-52]. Thus, the political party which won the most deputy seats in the elections or a number of political parties who won the same number of deputy seats introduces a candidate for the Prime Minister to the president. Here the President carries out a peculiar "filter" function, because he considers the proposed candidate in detail taking into account the interests of people of Uzbekistan and gives objective assessment to his position as worthy or unworthy. We believe that in this situation, opinion of the head of the state plays a key role on the candidate for the post of Prime Minister. Therefore, if the candidate proposed by a political party is not acceptable to him or not worthy candidate for prime minister in his eyes, without introduction of this candidate for consideration and approval by the chambers of the Oliy Majlis may require to provide another candidate and logically this is not contrary to the Constitution. After all, the head of the country considers the proposed candidate and is not forced to introduce him to the chambers of the Oliy Majlis, this is in his competence, it can lead to both positive and negative results. Otherwise, this norm will lose its importance and meaning. 
According to the $98^{\text {th }}$ Article of the Constitution of the Republic of Uzbekistan, "The nominee for the post of Prime Minister, upon consideration and approval of his nominee in the Oliy Majlis of the Republic of Uzbekistan, shall present the program of action of the Cabinet of Ministers for a short and long term prospect" [1, P. 52]. A nominee of the Prime Minister shall be deemed as approved, if more than half of the total number of deputies of the Legislative Chamber and members of the Senate of the Oliy Majlis of the Republic of Uzbekistan, respectively, vote for a nominee [1, P. 52].

Provision of the candidate for the post of the head of the government (appointed in some countries) of the country's representative body (or to its lower house) of a program is a common practice in the world, and has been used successfully in countries such as Albania, Hungary, France, Greece, Lithuania, Moldova, Poland, Portugal, Romania, Turkey, Finland, Macedonia, Croatia, Slovakia and serves to the expansion of the responsibility of the supreme body of the executive power in front of the supreme representative body, strengthening parliamentary system in the state governance. In contrast to many foreign countries, the Prime Minister in the Republic of Uzbekistan, hearing his program and discussing, approval of the candidate are within the competence of the both chambers of parliament. This, in turn, indicates the importance of the system of the state government of the Prime Minister status, further strengthens its responsibility before the Oliy Majlis. If he will not implement measures envisaged in the program after his appointment to the office, responsibility may be applied to him.

However, we think that attention in law-making should be paid to one issue: candidate for the post of Prime Minister introduces the program of action of the Cabinet of Ministers while his candidacy is considered and approved in the Oliy Majlis of the Republic of Uzbekistan for the near-term and long-term. However, does the logical analysis show that such a situation develops a program of action of the government and require governmental structure to be approved after discussion in its meeting? After all, the Cabinet of Ministers relinquishes its powers before the newly elected Oliy Majlis.

In this case, it is important to form the structure of forming the Cabinet of Ministers of the Republic of Uzbekistan in the legislation, according to which the nominee of a Prime Minister of the Republic of Uzbekistan shall be proposed by a political party, securing the highest number of seats in the elections to the Legislative Chamber of the Oliy Majlis of the Republic of Uzbekistan or by several political parties, securing the equal highest number of seats. After a nomination of the Prime Minister is approved by the chambers of the Oliy Majlis, he forms the composition of the Cabinet of Ministers in agreement with the head of the state. After the formation of the composition of the government, the near-term and long-term program of action of the Cabinet of Ministers is developed and introduced by the Prime Minister to the chambers of the Oliy Majlis. Approving the program of action of the government means the vote of confidence to the Cabinet of Ministers. This analogous practice has been successfully used in this or that form in France, the Czech Republic, Estonia, Poland, Italy and other countries and means that we should focus on the above suggestions and recommendations.

The structure of the Cabinet of Ministers of the Republic of Uzbekistan, members of the government after the approval of the Prime Minister by the chambers of the Oliy Majlis on the above-mentioned procedure is appointed by the head of the state on his proposal. Thus, the parliament of the country does not participate in the appointment of members of the Cabinet of Ministers. However, the duration of introduction of proposal of the Prime Minister to the President on the candidate of members of the Cabinet of Ministers in the legislation, is not defined. For that reason, the Article 4 of the Law "On the Cabinet of Ministers of the Republic of Uzbekistan" must be completed with the eighth chapter on "The Prime Minister from the date of approval by the Oliy Majlis of the Republic of Uzbekistan, introduced within ten days for the approval of the composition of the Cabinet of Ministers to the President of the Republic of Uzbekistan". After all, the issue of a period is important in this political process.

At the same time, it is time to pay attention to the issue of attraction of the supreme representative body to the process of appointment of members of the government. The reason for this is that the essence of democratic reforms being implemented in the sphere of state power and administration, taking into account implementation of the constitutional principle of governance, further strengthening the practical embodiment of the concept of parliamentary system in government, these measures expand responsibilities of the Cabinet of Ministers before the Parliament, serves to appointment of persons supported by parliament to membership of this body, improvement of the mechanism of parliamentary control, strengthen relations of members of the government with members of parliament, as well as stabilize relations between the legislative and executive authorities. 


\section{Conclusion:-}

It should be noted that a detailed analysis of the process of formation of the Cabinet of Ministers of the country shows that this is complex and important step, where the participation of parliament and the head of the state is carried out in the defined order as in the developed democratic countries, which, in turn, serves as one of the main factors in the effectiveness of stability and democratic reforms in the country.

\section{References:-}

1. Constitution of the Republic of Uzbekistan. - T.: «Uzbekistan», 2014. - 76 P.

2. Constitutional Law No. LRU-88 of April 11, 2007 «On strengthening the role of political parties in renewal and further democratization of state governance and modernization of the country» // Bulletin of the legislative acts of the Republic of Uzbekistan, 2007, No. 15, Article 151

3. Law No. LRU-284 of April 18, 2011 «On introducing amendments and addenda to some articles of the Constitution of the Republic of Uzbekistan (to the Articles 78, 80, 93, 96 and 98)» // Bulletin of chambers of the Oliy Majlis of the Republic of Uzbekistan, 2011, No. 4, Article 100.

4. Azizkhodjaev A.A. The real Uzbek’s feat. - T.: «Uzbekistan», 2011.- P. 493. 